$$
\text { DOE/PC/952/5- - TI }
$$

\title{
DETERMINATION OF THE FORMS OF NITROGEN RELEASED IN COAL TAR DURING RAPID DEVOLATILIZATION
}

\section{Dequitennual Report}

Principal Investigator: Thomas H. Fletcher

Grant No. DE-FG22-95PC95215

Chemical Engineering Department Brigham Young University Provo, UT $\mathbf{8 4 6 0 2}$

April 30, 1996

Date of Grant: August 1, 1995

Anticipated Completion Date: July 31, 1997

Government Award: $\mathbf{\$ 5 0 , 0 0 0}$ for first year

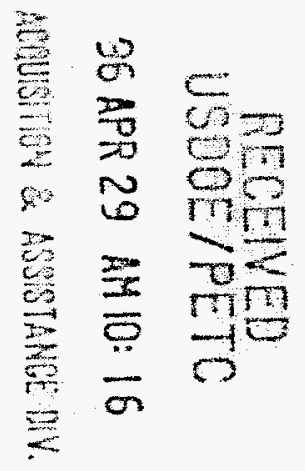

Program Manager: Philip Goldberg

Contracting Officer Representative (COR): Philip Goldberg

Reporting Period: November 1, 1995 to April 30, 1996

(U.S. DOE Patent Clearance is not required prior to the publication of this document) DISTRIBUTION OF THIS DOCUMENT IS UNLIMITED 


\section{DISCLAMMER}

Portions of this document may be illegible in electronic image products. Images are produced from the best available original document. 


\section{DISCLAIMER}

This report was prepared as an account of work sponsored by an agency of the United States Government. Neither the United States Government nor any agency thereof, nor any of their employees, makes any warranty, express or implied, or assumes any legal liability or responsibility for the accuracy, completeness, or usefulness of any information, apparatus, product, or process disclosed, or represents that its use would not infringe privately owned rights. Reference herein to any specific commercial product, process, or service by trade name, trademark, manufacturer, or otherwise does not necessarily constitute or imply its endorsement, recommendation, or favoring by the United States Government or any agency thereof. The views and opinions of authors expressed herein do not necessarily state or reflect those of the United States Government or any agency thereof. 


\section{INTRODUCTION}

Control of emissions of nitrogen oxides $\left(\mathrm{NO}_{\mathrm{x}}\right)$ from coal combustion systems is becoming a major design and retrofit consideration. Most $\mathrm{NO}_{\mathrm{x}}$ in coal combustion systems comes from nitrogen in the fuel, rather than from nitrogen in the air. Practical emission control strategies include burner design strategies (e.g., low $\mathrm{NO}_{\mathrm{x}}$ burners), overfire air, reburning, selective non-catalytic reduction (SNCR) using reduction agents such as $\mathrm{NH}_{3}$ or urea, and selective catalytic reduction (SCR). The order listed also reflects the order of increasing costs for implementation. It is therefore most economically desirable to perform burner modifications to reduce $\mathrm{NO}_{\mathrm{z}}$ emissions rather than other control measures.

Low- $\mathrm{NO}_{\mathrm{x}}$ burners work on the principle that devolatilized nitrogen species will form $\mathrm{N}_{2}$ rather than $\mathrm{NO}_{\mathrm{x}}$ under locally fuel-rich conditions with sufficient residence time at appropriate temperatures. The amount and form of nitrogen released during devolatilization influence the degree of $\mathrm{NO}_{\mathrm{x}}$ reduction attainable using burner design strategies for a given coal. Nitrogen in the char following devolatilization is released by heterogeneous oxidation, and may not be controlled by aerodynamic burner modifications.

The use of comprehensive computer modeling is becoming an efficient screening method in the design of new systems, when based on sound fundamental understanding of the systems to be modeled. Although several empirical relationships for nitrogen evolution from coal during devolatilization have been developed, the fundamental chemistry of coal nitrogen evolution is still not fully understood, and is a weak link in comprehensive coal combustion models used for screening of new systems.

The objectives this work are to perform detailed chemical measurements of the forms of nitrogen in coal, char, and tar. Questions to be answered by this research fall into two categories:

1. Why do low rank coals (i.e., lignites) release as much nitrogen during devolatilization as hva bituminous coals when the tar yields are markedly different?

2. Why do coals of similar rank and elemental composition release different amounts of nitrogen during devolatilization?

Seven tasks are proposed to help answer these two questions:

1. Obtain representative coals being used or considered for use by industry. This includes eight coals from Dr. Pershing at the U. of Utah that will be used in his research for the DOE-HiPPS and DOE-LEBS programs.

2. Analyze parent coals for:

- elemental nitrogen content

- extract yield

- elemental composition of extracts

- XPS nitrogen form (5-member, 6-member, etc.)

- ${ }^{15} \mathrm{~N}$ NMR spectra

3. Collect char samples in the FFB under $0 \%$ post-flame $\mathrm{O}_{2}$ conditions. Determine the fraction of nitrogen released during pyrolysis at high heating rates and temperatures in the FFB. Also perform XPS and $15 \mathrm{~N}$ NMR experiments on selected FFB chars.

4. Perform HPCP pyrolysis experiments to collect tar and char samples as a function of residence time and temperature. Determine the fraction of nitrogen 
released during pyrolysis at high heating rates and temperatures. Also perform XPS and ${ }^{15}$ N NMR experiments on selected HPCP chars and tars.

5. Perform solvent extractions on parent coals and partially-devolatilized coal chars, saving both extract and residue samples. Analyze residues and extracts for elemental composition. Perform $15_{\mathrm{N}} \mathrm{NMR}$ and high resolution chromatography experiments on extracts to look for changes in the forms of nitrogen as a function of coal type and extent of devolatilization.

6. Perform new NMR experiments (i.e., DNP) to better characterize forms of nitrogen in coal, coal char, and tar.

7. Develop a model of nitrogen release as a function of coal type based on chemical forms of nitrogen in coal.

\section{EXPERIMENTAL APPARATUS}

This research focuses on the solid and liquid products produced during coal devolatilization. These include coal chars, tars and solvent extraction products of char. To produce the devolatilized products two systems were used: a drop tube reactor (HPCP) and a flat flame burner (FFB). The HPCP has been used to perform moderate temperature experiments ( 800 to $1200 \mathrm{~K}$ ) at atmospheric pressures to provide char and tar samples as a function of residence time during devolatilization. The FFB experiments provide char and soot samples from a high temperature, high heating rate environment with products of methane combustion present.

\section{SUMMARY OF TECHNICAL PROGRESS}

The cost-shared part of this project started on May 1, 1995, and the DOE part started on August 1, 1995. Accomplishments from November 1, 1995 to April 30, 1996 include:

- Completion of a detailed set of pyrolysis experiments in the HPCP and FFB that included 5 coals pyrolyzed at 6 different conditions. These experiments provided char and tar samples for further analysis.

- Determination of chemical structure features of coal and char samples (produced in the HPCP at moderate temperatures) using previously-developed solid-state ${ }^{13} \mathrm{C}$ NMR techniques.

- Determination of chemical structure features of corresponding coal tar samples using a newly-developed high resolution liquid ${ }^{13} \mathrm{C}$ NMR technique.

- Theoretical analysis of the combined coal, tar, and char NMR data, resulting for in a balance on the number of aromatic clusters during pyrolysis and a determination of the number of nitrogens per aromatic cluster in the coal, tar, and char. This is the first time these kind of data have been available.

- Preliminary high resolution ${ }^{15} \mathrm{~N}$ NMR analyses of four coals, indicating potential variation in the forms of nitrogen found in coals of different rank.

- Preliminary work was started under the direction of Dr. Milt Lee involving tar samples to be analyzed with gas chromatography techniques.

- Further collaborative work with Dr. Simon Kelemen at Exxon Research to use XPS to analyze char samples produced in the HPCP. 


\section{HPCP and FFB Pyrolysis Experiments}

Chars and tars have been produced and collected for analysis in the HPCP drop tube reactor at conditions found in Table 1. Pyrolysis tests have been performed on the five coals listed in Table 2. The "D" designation on the PSOC number refers to the set of coal samples prepared under the direction of the DOE/PETC Direct Utilization AR\&TD program, and have been sieved and aerodynamically classified. The $63-75 \mu \mathrm{m}$ size fraction was used for all of the experiments. CHN analysis has been performed on all the chars and tars produced to date. Tar and char samples collected at the $320 \mathrm{~ms}$ condition from each of the five coals have been sent to Exxon for XPS analysis. Six matching samples of coal, char and tar were analyzed with the use of ${ }^{13} \mathrm{C}$ NMR. These samples include the three high volatile bituminous coals pyrolyzed at the $900 \mathrm{~K}$ and the $920 \mathrm{~K}$ condition. It is anticipated that the combination of analysis techniques will permit insight into the nitrogen evolution process.

\section{${ }^{13} \mathrm{C}$ NMR Analysis}

Solid state ${ }^{13} \mathrm{C}$ NMR techniques (CP/MAS and dipolar dephasing) have been used to determine the chemical structure features of coals and coal chars.(Orendt, et al., 1992, Solum, et al., 1989) In addition to carbon aromaticity $\left(f_{a^{\prime}}\right)$, the distinction between aromatic carbons with and without attachments (such as hydrogen, carbon, or oxygen) is measured. The specification of the number of aromatic carbons per cluster $\left(\mathrm{C}_{\mathrm{cl}}\right)$ provides the basis for the determination of many useful chemical structural features.(Solum, et al., 1989) Probably one of the most important quantities is the number of attachments per aromatic cluster, referred to as the coordination number $(\sigma+1)$, which helps determine the degree of crosslinking in the sample.

A high resolution ${ }^{13} \mathrm{C}$ NMR technique was recently developed and applied to model compounds, mixtures, and coal-derived liquid samples.(Bai, et al., 1995) This technique uses spin-lattice relaxation to differentiate protonated from nonprotonated carbons, based on relaxation differences arising from direct $\mathrm{CH}$ dipolar interactions. Average aromatic ring sizes and other lattice parameters are estimated using the procedures developed for solid-state ${ }^{13}$ C NMR.(Orendt, et al., 1992, Solum, et al., 1989)

Tar samples were dissolved in deuterated methylene chloride $\left(\mathrm{CD}_{2} \mathrm{Cl}_{2}\right)$ and then filtered. A significant amount of insoluble residue was obtained for each tar. This tar residue was subsequently analyzed using the same solid-state ${ }^{13} \mathrm{C}$ NMR technique as that used for coal char. The six tar samples from the three high volatile bituminous coals at the $900 \mathrm{~K}$ and $920 \mathrm{~K}$ condition were analyzed. The tars from the $920 \mathrm{~K}$ condition were the analyzed on a preliminary basis to determine the validity of the high resolution ${ }^{13} \mathrm{C} \mathrm{NMR}$ technique on coal tars. The analysis technique for coal tars did not, at first, account for a nonsoluble portion. Therefore the tar residues of this analysis were not analyzed. The analysis method was later modified to account for the tar residue portion in subsequent samples. This allowed for a more complete analysis of the tar from the $900 \mathrm{~K}$ condition.

The data from all the analyses are found in Tables 3 to 6 . The data from the $900 \mathrm{~K}$ condition include the combined tar values, calculated as a weighted average of the dissolved $\operatorname{tar}$ and tar residue. As seen in Table 4, 12 to $42 \%$ of the tar sample collected at the $900 \mathrm{~K}$ condition was insoluble in $\mathrm{CD}_{2} \mathrm{Cl}_{2}$ and was deposited on the filter as residue.

One of the most interesting features of these data are the average value of aromatic carbons per cluster $\left(\mathrm{C}_{\mathrm{cl}}\right)$. The $\mathrm{C}_{\mathrm{cl}}$ in the coal is 13 to 15 , which corresponds to structures with 3 to 4 aromatic rings. The values of $\mathrm{C}_{\mathrm{cl}}$ in the tar residue are similar to those found in the coal. Perhaps the most interesting finding is that the average cluster size of the 
dissolved tar ranges from 7 to 9 aromatic carbons. This is significantly lower than the values of 12 to 15 aromatic carbons per cluster found in the coal and tar residue (and the value of 15 to 18 in the char). The $\mathrm{C}_{\mathrm{cl}}$ of the combined tar is also much lower than the coal and the char.

\section{Nitrogen per Cluster in the Tar}

In a recent paper, Niksa(Niksa, 1994) postulated that nitrogen evolution during pyrolysis could be modeled assuming that the mass of nitrogen per aromatic cluster in the coal tar was equal to that in the parent coal. The previous quarterly report estimated the mass of nitrogen per cluster by assembling published data from several different investigators and making some assumptions. The information that was obtained in this quarter allows for the calculation of the mass of nitrogen per cluster for the first time from a single set of matching coal, char and tar samples, without making the assumptions of the previous analysis. The mass of nitrogen per cluster $M_{\text {cluster }}^{N}$ can be calculated as follows:

$$
M_{\text {cluster }}^{N}=\frac{x_{N}}{x_{C}} M W_{C} \frac{C_{c l}}{f_{a}}=M W_{c l} x_{N}
$$

$$
\begin{aligned}
& \mathrm{x}_{\mathrm{N}}=\mathrm{wt} \% \mathrm{~N} \text { in coal (daf) } \\
& \mathrm{x}_{\mathrm{C}}=\mathrm{wt} \% \mathrm{C} \text { in coal (daf) } \\
& \mathrm{MW}_{\mathrm{C}}=\text { molecular weight of carbon } \\
& \mathrm{C}_{\mathrm{cl}}=\# \text { of aromatic carbon per cluster } \\
& \mathrm{f}_{\mathrm{a}}{ }^{\prime}=\text { carbon aromaticity, or ratio of } \frac{\text { aromatic carbons }}{\text { total carbons }} \text { in coal or char } \\
& \mathrm{MW}_{\mathrm{cl}}=\text { molecular weight per aromatic cluster }
\end{aligned}
$$

Results of this analysis are shown in Fig. 1 for three coals pyrolyzed at moderate temperatures, indicating that the mass of nitrogen per cluster in the tars does not equal the mass of nitrogen per cluster in the parent coal. This result is interesting and has major implications regarding network devolatilization models, and therefore deserves further examination. Plans include similar NMR analyses of matching sets of coal tars produced at higher temperatures and greater extents of devolatilization (the char samples in Fig. 1 were only 50 to $75 \%$ pyrolyzed).

\section{N NMR Analysis}

The early stages of the ${ }^{15} \mathrm{~N}$ NMR spectroscopy work has focused on studies of simple nitrogen heterocycles. It was noted early that different types of nitrogen species respond in diverse ways during cross polarization experiments. The time constants governing $\mathrm{H}-\mathrm{N}$ cross polarization are dependent on the efficiency of spin diffusion, and this process is dependent on the motional characteristics and proximity of protons to the nitrogen functional groups in the coal samples. From model compound studies of isotopically enriched materials it has been observed that the proton-nitrogen cross polarization time constant can be as much as an order of magnitude longer for non-protonated nitrogens than for those with directly bonded hydrogens. Hence, one would expect the non-protonated nitrogens in 5- and 6-member ring structures to respond quite differently to those of protonated nitrogens in similar ring systems. We have, in fact observed such behavior. (Solum, et al. 1996) Given the short values for the proton $T_{1 \rho}$ in coals, we have concluded that relative intensity of non-protonated nitrogens will be no greater than $1 / 5-1 / 4$ that of an equivalent number of protonated nitrogens. Hence, all that one can expect to detect is pyrrolic and quaternary forms of nitrogen species in coal samples. These model 
compound data explain the "apparent" absence of pyridinic nitrogens in the $15 \mathrm{~N}$ spectra that have been published on coals.(Davidson, 1994, Knicker, et al., 1995)

$15 \mathrm{~N}$ NMR studies at the natural abundance level have been especially difficult for two basic reasons: 1) the low receptivity of the nitrogen nucleus $\left(0.065\right.$ relative to the ${ }^{13} \mathrm{C}$ nucleus) and 2) the low nitrogen concentration in coals (typically 1-4 percent). Thus, standard NMR methods for obtaining ${ }^{15} \mathrm{~N}$ NMR data in coals have been frustrating even though a few spectra (taken with accumulation of $1.5-2.5 \times 10^{6}$ scans but of low $\mathrm{S} / \mathrm{N}$ ) have been measured.(Davidson, 1994, Knicker, et al., 1995) Taking advantage of high field strength ( 9.4 tesla) provides some advantage, but the sensitivity problem will require additional innovations if one is to significantly improve the quality of data obtainable. That such innovations may be possible has recently been demonstrated in preliminary experiments.(Hu, et al., 1996) Using a sample doped with a stable free radical, we observed an enhancement factor in the 500-1000 range by employing the dynamic nuclear polarization experiment to a model compound. Further experiments are presently under way.

We have recently obtained ${ }^{15} \mathrm{~N}$ NMR data on a series of coals of different ranks (lignite, subbituminous, high volatile bituminous, and low volatile bituminous), as shown in Figure 2. The $S / N$ is rather poor even with the acquisition of ca $4 \times 10^{5}$ scans per spectrum taken at a magnetic field strength of 9.4 tesla. As expected from the standard cross polarization experiment, only the protonated pyrrolic nitrogens are abserved, as the used contact time of $1 \mathrm{msec}$ is too short to polarize non-protonated nitrogen nuclei. A careful examination of these four spectra indicates that differences do exist in the types of pyrrolic structures observed. The rather broad signal moves to higher field with coal rank and, in the case of Pocahontas \#3, two distinct resonance lines (confirmed by carrying out multiple duplicate experiments) are observed in the pyrrole/carbazole chemical shift region.

\section{Nitrogen-Specific Chromatography and XPS Analyses}

Nitrogen-specific chromatography of coal tars produced in the HPCP was initiated this reporting period, in collaboration with Professor Milt Lee at BYU. Initial results indicate challenges with the high molecular weight of coal tars. In addition, coal tars were sent to Exxon for XPS analysis, and the resulting data are currently being analyzed.

\section{Flat Flame Burner Experiments}

Flat-flame burner experiments on additional coals was initiated this reporting period, and will continue into the next reporting period.

\section{FUTURE PLANS}

Future plans includes expanding the matrix of HPCP pyrolysis conditions to include (i) shorter residence times and (ii) higher temperatures. This will permit examination of samples from early to late devolatilization. Char and tar samples from the five coals already tested in the HPCP will be analyzed by researchers at Exxon research using the XPS technique. The FFB burner will be used to obtain char and soot samples at a maximum temperature of $1700 \mathrm{~K}$ for a number of coals. Further analysis of tar samples will be performed using NMR techniques to determine the nitrogen per cluster, and the tar values will be compared with the coal values. 


\section{REFERENCES}

Bai, S., R. J. Pugmire, C. L. Mayne and D. M. Grant, Analytical Chemistry , 67, 34333440 (1995).

Davidson, R. M. "Nitrogen in Coal," IEA Coal Research, ISBN 92-9029-230-X (1994).

Hu, J. Z., J. Zhou, B. Yang, L. Li, J. Qiu, C. Ye, R. J. Pugmire, M. S. Solum, W. R. and D. M. Grant, submitted to Solid State NMR , (1996).

Knicker, H., P. G. Hatcher and A. W. E. F. Scaroni, Energy and Fuels , 9, 999 (1995).

Niksa, S., In 25th Symposium (Int.) on Combustion; The Combustion Institute, Pittsburgh, PA, pp 537 (1994).

Orendt, A. M., M. S. Solum, N. K. Sethi, R. J. Pugmire and D. M. Grant, ${ }^{13}$ C NMR Techniques for Structural Studies of Coals and Coal Chars, In Advances in Coal Spectroscopy, H. L. C. Meuzelaar, Ed., Plenum Press, New York, pp 215-254 (1992).

Solum, M. S., K. A. Altman, M. Strohmeyer, D. Berges, Y. Zhang, J. C. Facelli, R. J. Pugmire and D. M. Grant, , submitted for publication (1996).

Solum, M. S., R. J. Pugmire and D. M. Grant, Energy and Fuels , 3, 187 (1989).

\section{PUBLICATIONS/PRESENTATIONS RELATED TO THIS CONTRACT}

1. Fletcher, T. H., M. Watt, S. Bai, M. S. Solum, and R. J. Pugmire, "Chemical Structure of Coal Tar During Devolatilization," ACS Division of Fuel Chemistry preprints, 41(2), 752-755, New Orleans, LA (March 1996).

2. Watt, M., E. Hambly, D. Genetti, and T. H. Fletcher, "Nitrogen Release During Coal Devolatilization," poster presented at the Tenth Annual Technical Conference, Advanced Combustion Engineering Research Center, Salt Lake City, UT (March 1996).

3. Watt, M., T. H. Fletcher, S. Bai, M. S. Solum, and R. J. Pugmire, "Chemical Structure of Coal Tar During Devolatilization," accepted for presentation and publication at the Twenty-Sixth Symposium (International) on Combustion, Naples, Italy (July 1996).

4. Watt, M., "The Chemical Structure of Coal Char and Tar During Devolatilization," M.S. Thesis, Chemical Engineering Department, Brigham Young University, Provo, Utah (April, 1996). 
Table 1

Experimental Conditions for the Five PETC Coals

\begin{tabular}{|c|c|c|c|}
\hline Equipment & $\begin{array}{c}\text { Maximum Gas } \\
\text { Temp. }(\mathbf{K})\end{array}$ & $\begin{array}{c}\text { Residence } \\
\text { Time(ms) }\end{array}$ & $\begin{array}{c}\text { Gas } \\
\text { Atmosphere }\end{array}$ \\
\hline HPCP & 850 & 140 & $\mathrm{~N}_{2}$ \\
\hline HPCP & 900 & 160 & $\mathrm{~N}_{2}$ \\
\hline HPCP & 920 & 320 & $\mathrm{~N}_{2}$ \\
\hline HPCP & 1050 & 210 & $\mathrm{~N}_{2}$ \\
\hline HPCP & 1220 & 230 & $\mathrm{~N}_{2}$ \\
\hline FFB & 1650 & 15 & $0 \% \mathrm{O}_{2}$ \\
\hline
\end{tabular}

Table 2

Coals Examined in the HPCP

\begin{tabular}{|l|l|c|}
\hline Coal & \multicolumn{1}{|c|}{ Rank } & PSOC Number \\
\hline Beulah Zap & lignite & 1507D \\
Illinois \#6 & hva bituminous & $1493 \mathrm{D}$ \\
Pittsburgh \#8 & hva bituminous & $1451 \mathrm{D}$ \\
Blue \#1 & hva bituminous & $1445 \mathrm{D}$ \\
Pocahontas \#3 & lv bituminous & 1508D \\
\hline
\end{tabular}

Table 3

${ }^{13} \mathrm{C}$ NMR Analysis of Coals, Tars, and Chars ${ }^{\mathrm{a}}(160 \mathrm{~ms}$ at $900 \mathrm{~K})$

\begin{tabular}{|c|c|c|c|c|c|c|c|c|c|c|c|c|c|}
\hline Coal & Sample & $\mathrm{f}_{\mathrm{a}}$ & $\mathrm{f}_{\mathrm{a}} \mathrm{C}$ & $\mathrm{f}_{\mathrm{a}^{\prime}}$ & $\mathrm{f}_{\mathrm{a}} \mathrm{H}$ & $f_{a} N$ & $f_{a}{ }^{P}$ & $\mathrm{f}_{\mathrm{a}} \mathrm{S}$ & $f_{a}{ }^{B}$ & $\overline{f_{a l}}$ & $\mathrm{f}_{\mathrm{al}} \mathrm{H}$ & $\mathrm{f}_{\mathrm{al}}{ }^{*}$ & $\mathrm{f}_{\mathrm{al}} \mathrm{O}$ \\
\hline Pitt \#8 & coal & 65 & 3 & 62 & 23 & 39 & 5 & 16 & 18 & 35 & 24 & 11 & 7 \\
\hline$\overline{\text { Pitt \#8 }}$ & char & 87 & 5 & 82 & 27 & 55 & 6 & 19 & 30 & 13 & 7 & 6 & 3 \\
\hline Pitt \#8 & tar dis. & 69 & 2 & $\overline{67}$ & 38 & 29 & 5 & 15 & $\overline{9}$ & 31 & 2 & 11 & $\overline{n a}$ \\
\hline Pitt \#8 & tar res. & 83 & 3 & 80 & 34 & 46 & 8 & 18 & 2 & 17 & 1 & 7 & 2 \\
\hline Pitt \#8 & $\operatorname{tar}$ & 73 & $\overline{2}$ & 70 & 37 & 33 & 6 & 16 & 12 & 28 & 18 & 10 & na \\
\hline & & & & & & & & & & & & & \\
\hline Mlinois \#6 & coal & 66 & 3 & 63 & 21 & 42 & 7 & 16 & 19 & 34 & 24 & 1 & 8 \\
\hline Mlinois \#6 & char & 74 & 4 & 70 & 23 & 47 & 7 & 18 & 22 & 26 & 17 & 9 & 4 \\
\hline Mlinois \#6 & tar dis. & 70 & 1 & 69 & 40 & 29 & 4 & 15 & 10 & 30 & 20 & 10 & na \\
\hline Illinois \#6 & tar res. & 80 & 6 & 74 & 28 & 46 & 8 & 18 & 20 & 2 & 12 & 8 & 3 \\
\hline Mllinois \#6 & $\operatorname{tar}$ & 74 & 3 & 71 & 35 & 36 & 6 & 16 & 14 & 26 & 17 & 9 & na \\
\hline & & & & & & . & & 1. & \% & & & . & 3 \\
\hline Blue \#1 & coal & 60 & 5 & 55 & 19 & 36 & 8 & 13 & 15 & 40 & 29 & 11 & 7 \\
\hline Blue \#1 & char & 71 & 7 & 64 & 20 & 44 & 8 & 14 & 22 & 29 & 21 & 8 & 4 \\
\hline Blue \#1 & tar dis. & 63 & 7 & 56 & 27 & 29 & 8 & 16 & 5 & 37 & 27 & 1 & na \\
\hline Blue \#1 & tar res. & 72 & 6 & 66 & 24 & 42 & 9 & 15 & 18 & 28 & 17 & 11 & 12 \\
\hline Blue \#1 & $\operatorname{tar}$ & 64 & 7 & 57 & 27 & 31 & 8 & 16 & 7 & 36 & 27 & 10 & na \\
\hline
\end{tabular}


Table 4

Derived Properties of Coal, Tar, and Char from the ${ }^{13} \mathrm{C}$ NMR analysis ${ }^{b}$ $(160 \mathrm{~ms}$ at $900 \mathrm{~K})$

\begin{tabular}{|c|c|c|c|c|c|c|c|c|c|c|}
\hline$\overline{\text { Coal }}$ & Sample & $\overline{\mathbf{X}_{\mathbf{b}}}$ & $\mathrm{C}_{\mathrm{cl}}$ & $\sigma+1$ & $\mathrm{P}_{0}$ & B.L. & $\widehat{\text { S.C }}$ & $\mathrm{MW}_{\mathrm{cl}}$ & $\mathrm{MW}_{\mathrm{att}}$ & \begin{tabular}{|l}
$\operatorname{tar}$ \\
res.
\end{tabular} \\
\hline Pitt \#8 & coal & 0.29 & 14 & 4.8 & $\overline{0.48}$ & 2.3 & 2.5 & 323 & $\overline{32}$ & \\
\hline Pitt \#8 & char & 0.366 & 18 & 5.4 & 0.76 & 4.1 & \begin{tabular}{|l|}
1.3 \\
\end{tabular} & 315 & 18 & \\
\hline Pitt \#8 & tar dis. & 0.134 & 8 & 2.4 & 0.45 & 1.0 & 1.4 & & & \\
\hline Pitt \#8 & tar res. & 0.25 & 12 & 3.9 & 0.73 & 2.8 & 1.1 & & & 0.25 \\
\hline Pitt \#8 & $\operatorname{tar}$ & 0.163 & $\overline{9}$ & 2.8 & 0.52 & 1.5 & 1.3 & 178 & 25 & \\
\hline & & & & & & 7. & & & & \\
\hline Illinois \#6 & coal & 0.30 & 15 & 5.5 & 0.52 & 2.9 & 2.6 & 368 & 35 & \\
\hline Illinois \#6 & char & 0.314 & 15 & 5.3 & 0.64 & 3.4 & 1.9 & 326 & 29 & \\
\hline Illinois \#6 & tar dis. & 0.144 & 9 & 2.5 & 0.47 & 1.2 & 1.3 & & & \\
\hline Illinois \#6 & tar res. & 0.27 & 13 & 4.6 & 0.69 & 3.2 & 1.4 & & & 0.42 \\
\hline Illinois \#6 & $\operatorname{tar}$ & 0.197 & 11 & 3.4 & 0.56 & 2.0 & 1.3 & 228 & 30 & \\
\hline & & & & & & & & & & \\
\hline Blue \#1 & coal & 0.27 & 13 & 5.0 & 0.48 & 2.4 & 2.6 & 371 & 42 & \\
\hline Blue \#1 & char & 0.344 & 17 & 5.8 & 0.64 & 3.7 & 2.1 & 402 & $\overline{34}$ & \\
\hline Blue \#1 & tar dis. & 0.09 & 7 & 3.0 & 0.58 & 1.7 & 1.3 & & & \\
\hline Blue \#1 & tar res. & 0.273 & 13 & 4.7 & 0.54 & 2.5 & 2.2 & & & 0.12 \\
\hline$\overline{\text { Blue \#1 }}$ & $\operatorname{tar}$ & 0.112 & 8 & 3.2 & 0.58 & 1.8 & 1.4 & 205 & 35 & \\
\hline
\end{tabular}

Table 5

${ }^{13} \mathrm{C}$ NMR Analysis of Coals, Tars, and Charsa $(320 \mathrm{~ms}, 920 \mathrm{~K})$

\begin{tabular}{|c|c|c|c|c|c|c|c|c|c|c|c|c|c|}
\hline Coal & ample & $f_{a}$ & $\mathrm{f}_{\mathrm{a}}^{\mathrm{C}}$ & $\mathrm{f}_{\mathrm{a}^{\prime}}$ & $\mathrm{f}_{\mathrm{a}}^{\mathrm{H}}$ & $\mathrm{f}_{\mathrm{a}}^{\mathrm{N}}$ & $\mathrm{f}_{\mathrm{a}}^{\mathrm{P}}$ & $\mathrm{f}_{\mathrm{a}} \mathrm{s}$ & $\mathrm{f}_{\mathrm{a}}^{\mathrm{B}}$ & $\mathrm{f}_{\mathrm{al}}$ & $\mathrm{f}_{\mathrm{al}} \mathrm{H}^{\mathrm{s}}$ & $\mathrm{fal}{ }^{*}$ & $\mathrm{f}_{\mathrm{al}} \mathrm{O}$ \\
\hline$\pi$ & al & $\overline{65}$ & $\overline{3}$ & 62 & 23 & 39 & 5 & 16 & 18 & 35 & 24 & 11 & \\
\hline Pitt \#8 & ar & 81 & 5 & 76 & 24 & $\overline{52}$ & 6 & 18 & 28 & 19 & 11 & 8 & 6 \\
\hline \begin{tabular}{|l|} 
Pitt \#8 \\
\end{tabular} & ar dis. & 76 & 5 & 71 & 35 & 36 & 10 & 19 & 7 & 24 & 9 & 15 & $\overline{\mathrm{na}}$ \\
\hline & & & & & & & & & & & & & \\
\hline Illinois \#6 & coal & 66 & 3 & 63 & 21 & 42 & 7 & 16 & 19 & 34 & 24 & 10 & 8 \\
\hline \begin{tabular}{|ll} 
Ilinois \#6 \\
\end{tabular} & char & 78 & 6 & 72 & 25 & 47 & 8 & 19 & 20 & 22 & 13 & 9 & 4 \\
\hline Illinois \#6 & $\operatorname{tar} \mathrm{dis}$ & 76 & 6 & 70 & 32 & 38 & 10 & 19 & - & 24 & 7 & 14 & na \\
\hline & & & & & & & & & & & & & \\
\hline Blue \#1 & coal & 60 & 5 & 55 & 19 & 36 & 8 & 13 & 15 & 40 & 29 & 11 & 1 \\
\hline Blue \#1 & har & 77 & 5 & 72 & 24 & 48 & 9 & 20 & 19 & 23 & 15 & 8 & 4 \\
\hline Blue \#1 & $\tan \mathrm{di}$ & 62 & 7 & 55 & 24 & 31 & 9 & 15 & 7 & 38 & 9 & 29 & \\
\hline
\end{tabular}


Table 6

Derived Properties of Coal, Tar, and Char from the ${ }^{13} \mathrm{C}$ NMR analysisb $(320 \mathrm{~ms}, 920 \mathrm{~K})$

\begin{tabular}{|c|c|c|c|c|c|c|c|c|c|}
\hline Coal & Sample & $\overline{\mathbf{X}_{\mathrm{b}}}$ & $\overline{C_{c l}}$ & $\sigma+1$ & $\overline{\mathbf{P}_{0}}$ & B.L. & $\overline{S . C}$ & $\overline{M W_{c l}}$ & $\mathrm{MW}_{\text {att }}$ \\
\hline Pitt \#8 & coal & 0.290 & 14 & 4.8 & 0.48 & 2.3 & 2.5 & 323 & $\overline{32}$ \\
\hline Pitt \#8 & char & 0.368 & 18 & 5.7 & 0.67 & 3.8 & 1.9 & 332 & 20 \\
\hline Pitt \#8 & \begin{tabular}{|l}
$\operatorname{tar}$ dis. \\
\end{tabular} & 0.100 & 8 & 3.3 & 0.69 & 2.3 & 1.0 & na & na \\
\hline Illinois \#6 & coal & 0,300 & 15 & 5.5 & 0.52 & 29 & 26 & 368 & 35 \\
\hline Illinois \#6 & char & 0.278 & 13 & 4.9 & 0.67 & 3.3 & 1.6 & 271 & 23 \\
\hline Ilinois \#6 & tar dis. & 0.130 & $\overline{8}$ & 3.3 & 0.76 & 2.5 & 0.8 & na & na \\
\hline & & & & & & & & & \\
\hline Blue \#1 & coal & 0.270 & 13 & 5.0 & 0.48 & 2.4 & 2.6 & 371 & 42 \\
\hline Blue \#1 & char & 0.344 & 17 & 5.8 & 0.64 & 3.7 & 2.1 & 402 & 34 \\
\hline Blue \#1 & tar dis. & 0.130 & 8 & 3.5 & 0.63 & 2.2 & 1.3 & na & na \\
\hline
\end{tabular}

apercentage carbon (error): $\mathrm{f}_{\mathrm{a}}=$ total $\mathrm{sp}^{2}$-hybridized carbon $( \pm 3) ; \mathrm{f}_{\mathrm{a}^{\prime}}=$ aromatic carbon $( \pm 4) ; \mathrm{f}_{\mathrm{a}} \mathrm{C}=$ carbonyl, $d>165$ ppm $( \pm 2) ; \mathrm{f}_{\mathrm{a}} \mathrm{H}=$ aromatic with proton attachment $( \pm 3) ; \mathrm{f}_{\mathrm{a}} \mathrm{N}=$ nonprotonated aromatic $( \pm 3) ; f_{a} P=$ phenolic or phenolic ether, $d=150-165$ ppm $( \pm 2) ; f_{a}{ }^{S}=$ alkylated aromatic $d=135-150$ $\operatorname{ppm}( \pm 3) ; \mathrm{f}_{\mathrm{a}} \mathrm{B}=$ aromatic bridgehead $( \pm 4) ; \mathrm{f}_{\mathrm{al}}=$ aliphatic carbon $( \pm 2) ; \mathrm{fal}_{\mathrm{a}} \mathrm{H}=\mathrm{CH}$ or $\mathrm{CH}_{2}( \pm 2) ; \mathrm{fal}_{\mathrm{al}}{ }^{*}=\mathrm{CH}_{3}$ or nonprotonated $( \pm 2) ; \mathrm{f}_{\mathrm{al}} \mathrm{O}=$ bonded to oxygen, $\mathrm{d}=50-90 \mathrm{ppm}( \pm 2)$, tar dis. $=$ tar that dissolved in $\mathrm{CD}_{2} \mathrm{Cl}_{2}$

${ }^{b} X_{b}=$ fraction of bridgehead carbons, $C_{c l}=$ aromatic carbons per cluster, $s+1=$ total attachments per cluster, $P_{O}=$ fraction of attachments that are bridges, B.L. $=$ bridges and loops per cluster, $S . C .=$ side chains per cluster, $\mathrm{MW} \mathrm{Cl}=$ the average molecular weight of an aromatic cluster, $\mathrm{MW}$ att $=$ the average molecular weight of the cluster attachments, $\operatorname{Tar}=\operatorname{tar}$ collected on filters and corrected for the tar deposited on sampling apparatus, tar dis. $=$ tar that dissolved in $\mathrm{CD}_{2} \mathrm{Cl}_{2}$ 


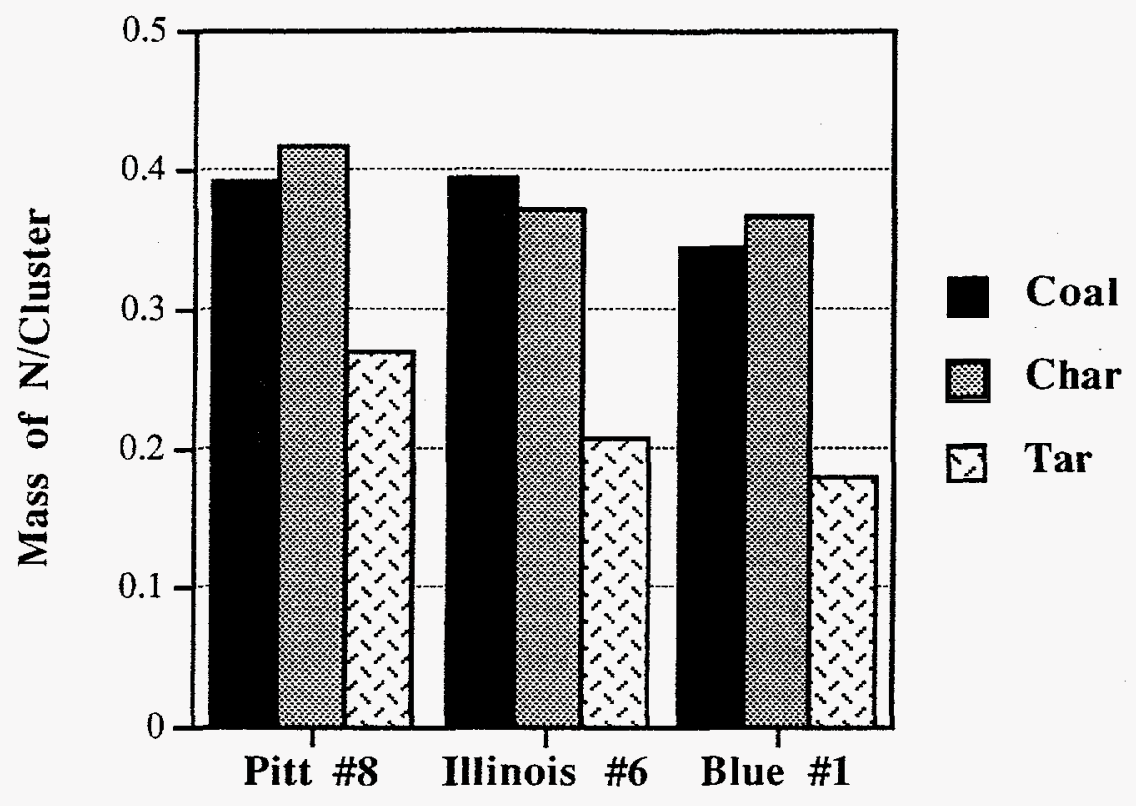

Figure 1. Mass of nitrogen per cluster $\left(M_{c l}^{N}\right)$ for the coal, char and combined tar. 


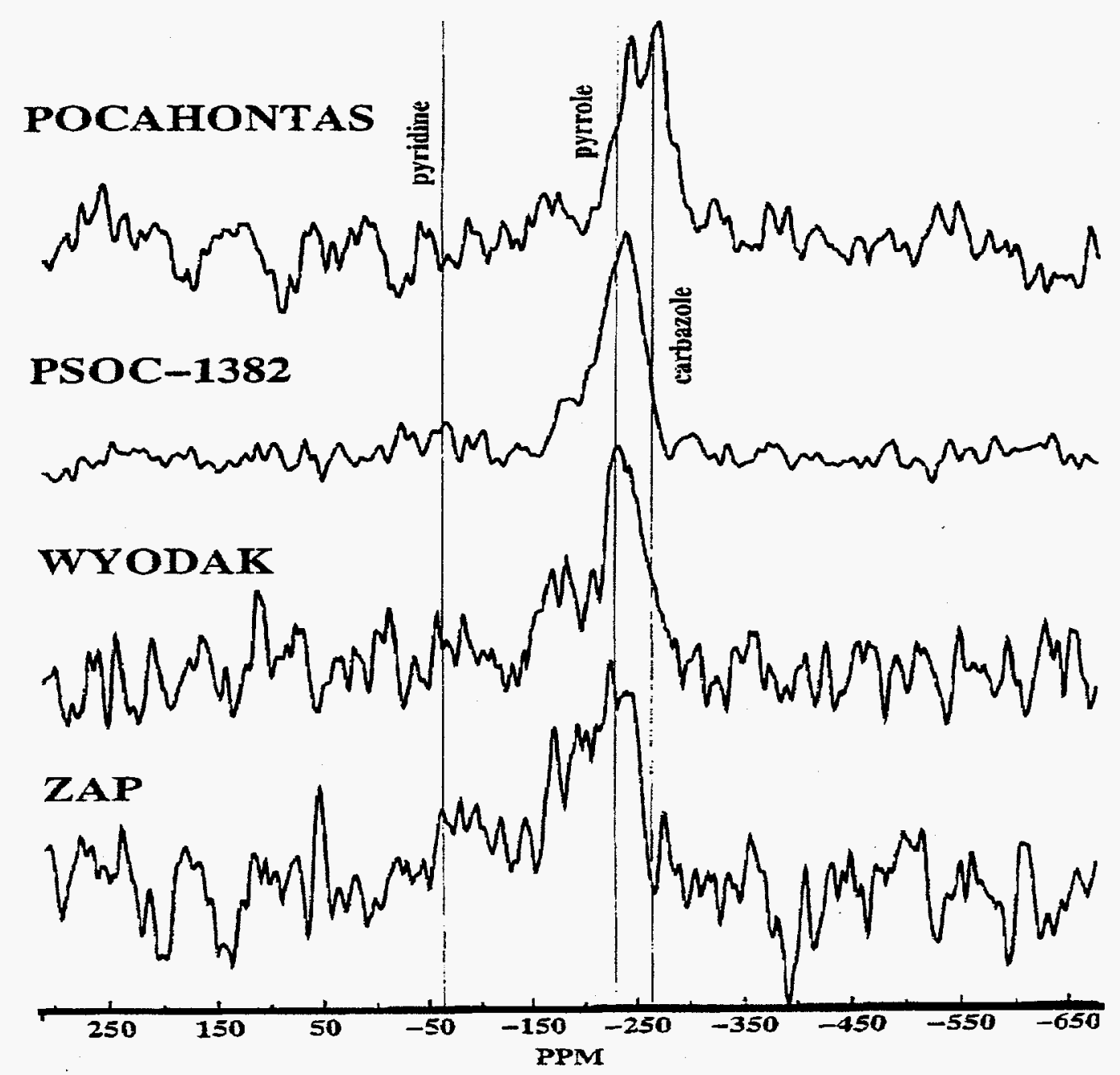

Figure 2. ${ }^{15} \mathrm{~N}$ CP/MAS NMR spectra of coals of different rank. The Zap, Wyodak, and Pocahontas \#3 are from the Argonne Premium Coal Sample Bank while PSOC-1382 was obtained directly from the Penn State Coal Bank. In each case a contact time of $1 \mathrm{~ms}$ was used with a recycle time of $200 \mathrm{~ms}$. A total of $4 \times 10^{5}$ scans was acquired for each spectrum. As demonstrated from the data contained in reference 1 the pyridinic nitrogens will not cross polarize efficiently and will be essentially invisible in this type of experiment. Only the pyrrolic nitrogens will be observed. 